\title{
THE MALAYAN INDIAN CONGRESS AND EARLY POLITICAL RIVALRY AMONG INDIAN ORGANISATIONS IN MALAYA, 1946-1950
}

\author{
Shanthiah Rajagopal* and Joseph Milton Fernando \\ Department of History, University of Malaya, Kuala Lumpur, MALAYSIA \\ *Corresponding author: rshanthiah@gmail.com
}

Published online: 27 April 2018

To cite this article: Rajagopal S. and J. M. Fernando. 2018. The Malayan Indian Congress and early political rivalry among Indian organisations in Malaya, 1946-1950. Kajian Malaysia 36(1): 25-42. https://doi.org/10.21315/km2018.36.1.2

To link to this article: https://doi.org/10.21315/km2018.36.1.2

\begin{abstract}
The Malayan Indian Congress (MIC) emerged amid the chaos of the immediate postwar period in Malaya to represent the interests of the minority Indian community. Several Indian leaders who had been involved in the Indian Independence League during the war decided that a national organisation was needed to serve as the voice of the Indian community. Within a few years, the party became the leading representative of the Indian community. But the MIC's transformation was not without serious challenges from within and from other Indian political movements. This article examines the early period of the party's history to trace the growth of the MIC into the leading political movement of the Indians in Malaya, its internal problems and significant rivalry with other Indian-based organisations during this period and the issues that arose. The article shows that a pragmatic approach by the party leadership, in particular its discontinuance of the boycott of the 1948 Federation Constitution and its principled position on citizenship, enabled the party to overcome the challenge posed by rival Indian organisations to become the leading voice of the Indians by 1950.
\end{abstract}

Keywords: Malayan Indian Congress, Malayan Indians, Malayan political movements, Federation of Indian organisations

\section{INTRODUCTION}

The Malayan Indian Congress (MIC), which celebrated its 70th anniversary recently, became the leading political party representing the Indians in Malaya by the early 1950s. This position, however, was only achieved after the party

(C) Penerbit Universiti Sains Malaysia, 2018. This work is licensed under the terms of the Creative Commons Attribution (CC BY) (http://creativecommons.org/licenses/by/4.0/). 
overcame considerable challenges from within the party and from rival Indianbased organisations in the early post-war period. This period of the early history of the MIC is often not well-understood nor has it been adequately researched in existing studies on Indians and Indian political organisations in Malaysia. Several works by Anbalakan provide significant discussion of aspects of political developments involving the MIC in the late 1940s and 1950s but his focus is on the identity question among the Indians in Malaya (Anbalakan, 2008; 2015) and does not discuss adequately the political rivalry and keen contest between the MIC and other Indian political organisations to represent the Indians in Malaya. Arasaratnam and Ampalavanar have touched on political developments among the Indians in the immediate post-war period but have not examined in depth the contest between the Indian-based parties (see Arasaratnam, 1970; Ampalavanar, 1981). Other studies on Indians in Malaya have largely focused on migration, labour and sociopolitical issues faced by the community (Sandhu, 1969; Mahajani, 1960; Stenson, 1980). This leaves a gap in the existing literature in regard to these early Indian political rivalries. Further, in recent years, more sources related to Indian-based organisations have become available in the archives and libraries and this enables a deeper consideration of these political rivalries. These sources include some recently available documents related to the MIC, Malayan Indian Association (MIA), and Federation of Indian Organisations (FIO); United Malays National Organization (UMNO) secretariat files related to the MIC activities; and also Colonial Office files (such as the CO 537 series) which contain useful information on the MIC. These recently-available sources now enable us to re-examine some of the developments related to the MIC and other Indian political organisations. It is clear that the MIC did not become the leading party of the Indians overnight. Rather, it was the result of the various pragmatic efforts of the early MIC leadership to build the party's strength and influence among the community as well as to stave off challenges from within the party and the contestation from rival Indian-based organisations in Malaya.

The MIC was founded shortly after the end of the Second World War in August 1945 to fill a need for a national organisation to represent the interests of the Indian community in Malaya. It was the culmination of a collective effort by several leaders to rally the Indians behind a national organisation that could safeguard the rights and interests of the minority community in the changing political environment in Malaya. Some of these leaders included those who had been detained by the British colonial government in 1945 for collaborating with the Japanese in Malaya during the war through their participation in the Indian Independence League (IIL) and the Indian National Army (INA) (Lebra, 1971: 202-209). The introduction of the Malayan Union scheme by the British colonial administration in April 1946 and the formation of the Malay communal party, UMNO, also accelerated the formation of the MIC in August 1946 (Stockwell, 1979: 
1-73). At the end of a three-day conference of a meeting of Indian organisations in Kuala Lumpur from 3-5 August 1946, the Malayan Indian Congress (MIC) was officially formed with John A. Thivy, one of the leading figures in the effort to form a national Indian political organisation, chosen as its first president. Having formed a national organisation for the Indians, the challenge facing the leaders was to obtain the support of the community. The article will first examine some of the early challenges faced by the MIC and then consider the rivalry with the other Indian-based political organisations in Malaya. The article will show that a series of pragmatic efforts undertaken by the MIC during this early formative period enabled the party to enhance its influence among the Indians and become the leading party of the community in Malaya.

\section{EARLY CHALLENGES FACED BY THE MIC}

One of the main challenges faced by the MIC after its formation in August 1946 was the political status and position of the domiciled Indian community. The Malayan Union scheme which came into force on 1 April 1946 had created a common citizenship encompassing the residents inhabiting all the Malay states and the Settlements of Penang and Melaka. The citizenship concept introduced for the first time under the Malayan Union scheme had the effect of creating categories of citizens and non-citizens whereas before that the Indians were considered as British subjects in Malaya (Ratnam, 1965: 75-118). UMNO had strongly opposed what it viewed as liberal conditions for citizenship for non-Malays under the Malayan Union scheme, apart from the erosion of the sovereignty of the Malay Rulers and the formation of a unitary state. The citizenship issue was thus a central issue among the Indian community in Malaya. The MIC at its inauguration in August 1946 decided that it would represent the interests of all Indians without taking into consideration their citizenship status (Jananayagam, 8 August 1946; Tamil Nesan, 8 August 1946). This was largely because the MIC leadership was still influenced by anti-British and anti-colonial sentiments. The MIC felt that the citizenship of Malaya that was offered did not have much value because the citizenship was not from an independent nation, but rather from a country that was still under British colonial rule. The MIC noted: "Malayans were, in effect, British subjects, a term which was a reminder of the subjugation of India and Malaya by the British" (Draft proposal of All-Malayan Indian Organisation, 3 August 1946). Thus the party felt that it would be wrong to differentiate between those who received citizenship and those who did not, as they in fact faced the same problems. The party was also concerned that any distinction between the two groups could lead to disunity among the Indians in Malaya. 
This objective of the MIC to serve both citizens and non-citizens was reiterated at the party's first general assembly in June 1947. Two decisions were made at the assembly and the decision to represent the non-citizens noted: "Indian settlers who want to retain their own nationality should have equality before the law, without having civic rights, should enjoy safety of person and property and should be treated in a generous and humane spirit" (see Annual Report of the MIC General Assembly, 1947/1948; and Indian Daily Mail, 10 June 1947). The MIC resolution to represent those who would be citizens of Malaya, urged the government to grant citizenship to those who lived in Malaya while also urging these people to obey the laws of the country and to give their undivided loyalty (Indian Daily Mail, 9 June 1947). The MIC's request to those who did not receive citizenship in a sense went beyond its bounds of duty. The MIC noted: "It is time that the rich and wealthy businessmen as well as landed property owners in this country stopped hugging to their pet belief that they would continue to exploit this country and at the same time escape the usual responsibilities of citizens or the inevitable disabilities of non-citizens" (Indian Daily Mail, 16 June 1947). The Indian Daily Mail noted that the MIC would face problems between citizens and non-citizens in future if its policy to represent both these groups was continued (Indian Daily Mail, 16 June 1947). The MIC, nevertheless, ignored the caution from the paper and at the early stages of its inception continued to represent both these groups. Thivy later noted that the Indians had forgotten that "under Nethaji it did not matter whether we were local born or Indian born, so long as we bore the stamp of Indians, he did not spare us" (Indian Daily Mail, 21 January 1949). Thivy urged the Indian community to stay clear of issues that could create controversy and division among the community and instead work towards positive objectives. It was only in 1949 that the MIC, on its own initiative, took the decision to change the party's objectives and to represent only those who had become citizens of the country. This showed that the MIC did face some problems in attempting to represent both these groups.

Another initial challenge faced by the MIC came in terms of opposition from the trade unions on the potential conflict of interest with the Indian political organisation. The MIC's proposal to include a "Labour Department" in the organisation was opposed by some trade unions which felt that this department strayed into their areas of interest. The All-Malaya States General Workers Union, for example, strongly disagreed with the formation of a labour department in the MIC (Draft Proposal All-Malaya Indian Organisation, 1946). Thivy, however, argued that the MIC had no axe to grind with the trade unions and the MIC was focused on the protection and advancement of the whole community (John Thivy's speech at MIC's First AGM, 1947). In addition, the General Labour Unions (GLU), for example, urged its delegates at the inaugural MIC meeting to oppose the setting up of a labour department (Anbalakan, 2015). And when the MIC decided to go- 
ahead with the formation of the labour department, the GLU staged a walkout and the GLU later discouraged its members from joining the MIC.

In attempting to be the leading party of the Indians in Malaya, the MIC faced numerous challenges from other similar-minded organisations in the early stages of its formation. Among the Indian-based organisations which posed a challenge to the MIC were the Indo-Malayan Association formed in Singapore in 1947 and the Malayan Indian Association. The Indo-Malayan Association was formed to represent Indians who were born in Malaya and Singapore (Indian Daily Mail, 16 September 1947). The members of this organisation emphasised that they should "live as Malayans - with the people and for the people of the land of its birth" (Indian Daily Mail, 16 September 1947). They took pride in stating that they were "Malayans first, Indians after" (Indian Daily Mail, 16 September 1947). The organisation reiterated Nehru's advice to the Indian community in Ceylon where he said he hoped that they would be "Ceylonese first, Indians after" (Indian Daily Mail, 16 September 1947). Nevertheless, the emergence of the Indo-Malayan Association and other organisations that represented Indians in Malaya were seen by some in the community as a threat to the unity and strength of the community (Indian Daily Mail, 10 September 1947).

The Indo-Malayan Association did not take seriously this accusation against the association and expressed its anger with those in the community who thought of themselves as "birds of passage," noting that "if this country is good enough to live in and to make money out of, it is good enough to die for" (Indian Daily Mail, 10 September 1947). Nonetheless, the Indo-Malayan Association did not have a significant impact among the community although in 1947 Indians who were born in Malaya made up $51.6 \%$ of the total Indians in Malaya (del Tufo, 1949). This was partly because the support and encouragement of the Indian government to the Indian community born in Malaya worked against the effectiveness of this association. This was particularly evident when Thivy was appointed the Government of India Representative in Malaya in 1947. Thivy often spoke on issues facing the Indian community while serving as the Indian government's representative in Malaya. Thivy was aware that the constitutional changes that would take place in Malaya would create a situation where only those who qualified would be granted citizenship. Thus there would emerge a distinction between the duties and obligations of citizens and non-citizens. Thivy assured the Indian community born in Malaya that they would receive the support of the Indian government (Indian Daily Mail, 17 September 1947). The Indo-Malayan Association did not receive much support also because the majority of Indians born in Malaya did not want to distinguish themselves from those immigrant Indians. The role of the Indian community in the IIL and INA, sentiments towards India and the role played by the Indian government in representing the Indian community in Malaya led to the adoption of this liberal attitude among Indians born in Malaya. 
Another organisation which also held similar objectives to the IndoMalayan Association was a peninsular-based organisation called the Malayan Indian Association (MIA). The MIA, which was formed by G. V. Thaver in 1932, was revived again on 15 August 1947 with its headquarters based in Kuala Lumpur. One of the main objectives of the MIA was to "promote and safeguard the general interests, rights and welfare of the Malayan Indians" (Malayan Indian Association, File 104/50). The association sought to distinguish between "Malayan Indians" and those who were non-citizens. The MIA interpreted "Malayan Indians" as those who considered Malaya and Singapore as their permanent place of residence and were qualified to obtain citizenship in accordance with the 1948 Federation of Malaya Agreement (Malayan Indian Association, File 104/50). The membership of MIA did not include Indian immigrants who were represented by the MIC at the time. The presence of V. M. N. Menon, an MIC official, in the MIA as its deputypresident led to a less than encouraging support for the MIA from the Indian community. Menon had been a member of the Ross Committee in 1946 which examined the sale of toddy in Malaya. When the Ross committee's report was sent to the Advisory Council on 10 March 1947, the government made the decision that all toddy shops in estates that were closed during the war will not be opened, and toddy shops outside the estates will be closely monitored (see Report of Malayan Union Advisory Council Proceedings, 1947-1948). S. B. Palmer, the chairman of the United Planting Association of Malaya (UPAM), proposed some changes to the decision and stated that all toddy shops in the estates should be closed at the expiry of their licences. Menon opposed this move by Palmer to close all toddy shops in estates. His vote was the deciding vote that defeated the amendment which would have closed all toddy shops. Menon's action aroused anger from the MIC which was the main proponent of the total ban on the sale of toddy. His action not only went against MIC policy but was seen as a "crime" towards the community for allowing the continued sale of toddy. Thus, Menon was sacked from the MIC following this development (see Indian Daily Mail, 9 July 1947; Straits Times, 10 June 1947).

The MIA, as was also the case of the Indo-Malayan Association in Singapore, did not obtain much support from the Indian community. The MIA's membership in 1949 amounted to 100 members (MIA File, 104/50). The MIC membership in June 1947, a year after its formation, was estimated at 20,000 (Indian Daily Mail, 12 June 1947) and this rose significantly to 44,000 in 1957 (see MIC File, 114/58). The membership of the MIA showed that the organisation was not very effective in gaining the support of the community since its formation and it was dissolved on 23 June 1959. One of the main reasons for the small membership of the MIA was the fact that the association was largely limited to the confines of Kuala Lumpur and although efforts were made to set up branches outside Kuala Lumpur, they were not successful (MIA File 104/50). Compared to the MIA, the 
MIC had already set up 52 branches throughout Malaya in the first year after its formation (see MIC Annual Report, 1946/1947; Indian Daily Mail, 10 June 1947). This situation led to the Registrar of Societies adopting the view that the revived post-war MIA was not formed to represent the Indian community but rather was an effort by a group of Indians to oppose the MIC (MIA File 104/50). While the MIA argued that it would represent Indians born in Malaya, it was not explained to what extent such representation would differ from the objectives of the MIC.

The discussion above shows that the Indo-Malaya Association and the MIA which restricted its membership to those born in Malaya, had a limited influence and following in the country. The question of distinguishing between Malayan citizens and non-citizens, however, remained a serious issue. The MIC itself subsequently changed its position on the issue. In 1949, the MIC made a major change in its policy position and stated that it would restrict it membership to Indians who considered Malaya as their country and gave their undivided loyalty to the country (see New draft MIC Constitution, 1949; Indian Daily Mail, 22 June 1949). There was also a suggestion from within the MIC to change the party's name to Malayan National Indian Congress (MNIC) to emphasise the national character of the party and the fact that the party included members from the smaller Ceylonese and Pakistani communities (see CO 537/6019, Pan-Malayan Intelligence Report, June 1949).

\section{SHIFT IN MIC'S POLICY}

An important factor that brought about the change in the MIC's position was the difficulty in formulating policies that could fulfill the needs of both the citizens and non-citizens (see Budh Singh's speech, Third MIC AGM, 1949). MIC president Budh Singh explained in 1949 that the exemption of those who did not consider Malaya as their home was largely to prevent these people from intervening in MIC party activities. He noted that the participation of this group in discussions within the MIC had complicated MIC policy-making and weakened the party. N.T.R. Singam, the president of the Selangor Regional Indian Congress, supported the changes to the MIC constitution and criticised the participation of non-citizens in MIC as an intrusion. He noted: "This is aggression against the Malayan people. We cannot fly foreign flags, shout foreign slogans, sing foreign national anthems, give our loyalties to a foreign country and at the same time want to meddle in the affairs of Malaya. To continue to do so is to arouse the hostility of the Malayan people" (Malaya Tribune, 4 July 1949). Singam argued that the Indian community should show undivided loyalty to Malaya before making demands on their rights (Tamil Nesan, 8 July 1949). He added that Indian nationals who did not obtain Malayan citizenship would be represented by the Government of India representative in 
Malaya (see CO 537/2562, File on Nationality of Indians). The confusion between citizens and non-citizens raised concerns about the possibility of a situation similar to Burma and Ceylon arising wherein the properties and business of Indians were confiscated and they were forced to return to India (Indian Daily Mail, 29 June 1949).

Another factor which contributed to the change in the MIC policy was the political developments related to the Malay and Chinese communities. UMNO at that point proposed the opening of its doors to non-Malays who were citizens of Malaya. The UMNO general assembly at its meeting on 28 May 1949 in Perlis had made a decision to open the party's membership to non-Malays as associate members (Straits Times, 30 May 1949). This move was championed by Dato' Onn Jaafar who wanted to convert UMNO into a non-communal national political organisation. The MCA, on the other hand, was opening its doors to all Chinese who considered Malaya as their home (Straits Times, 28 February 1949). It was obvious that the Malay and Chinese communities were preparing themselves to be involved in the government that would in future be formed in Malaya. The MIC leadership was aware of these political developments and began to question the ability of the MIC to obtain recognition from the government and also support from other communal parties. They felt that this would depend on the MIC changing and evolving into a national organisation that represented the Indian community in Malaya (UMNO/SG, File No. 113/50).

The objectives that were proposed in the MIC's new draft constitution clearly showed the willingness of the MIC to participate in the changing political environment and indeed the new government that would eventually be formed in Malaya (see Draft of MIC's new constitution, 1949). The MIC leaders also wanted to ensure that the MIC was seen as the national organisation that represented the Indians in Malaya. Budh Singh explained that cooperation with the other communities should be improved to achieve this objective (see Budh Singh's speech, Third MIC AGM, 1949). The MIC secretary noted the support of the other communities to the changes suggested to the structure of the MIC (Indian Daily Mail, 29 June 1949). However, the effort to restructure the MIC in 1949 was not successful. On 10 July 1949, the All-Malayan Indian Congress Committee (AMICC) in its third annual session decided that the draft of the new constitution that was proposed by the MIC Working Committee would be considered at a special session of the MIC at a future date.

The efforts to restructure the MIC failed because of resistance from the lower echelons of the MIC although the party leadership at the national level and the Selangor Regional Indian Congress strongly supported the proposed changes (Indian Daily Mail, 4 and 7 July 1949). The MIC branches from Johor Bahru, Tapah, Telok Anson and Pulau Pinang were among those who rejected the draft constitution. The Singapore Regional Indian Congress (SRIC) strongly rejected 
the draft constitution and stressed that it will continue to function under the old constitution if the MIC accepted the draft of the new constitution (Indian Daily Mail, 5 July 1949). The Indian Daily Mail in eleven of its editorials between June and July 1949 analysed and questioned the motives and arguments related to the proposed changes to the party constitution and urged the AMICC members to reject the proposed changes (see Editorials in the Indian Daily Mail of 24, 27, 28 and 29 June, 1949; 1 to 7 July, 1949). One of the main factors that contributed to opposition to the proposed changes in the MIC was the issue of citizenship and the welfare of the Indian community. The Indian Daily Mail which led this opposition campaign, for instance, argued that the MIC was formed to represent all Indians in Malaya, including "those who are born and bred in this country and those who are not, those who regard Malaya as their permanent home and those who do not, those who are members and those who are not, in fact all classes and categories of Indians" (Indian Daily Mail, 24 June 1949).

Any attempt to exclude any of these groups was viewed as diverting from the original aims and motives of the formation of the party. The newspaper further argued that the unity of the Indian community should not be disregarded in order to fulfill the political importance of any single group and observed: "Political differences and groupings are one thing; racial unity and solidarity is another. Whether they take up Malayan citizenship or not, whether they have made or they decide to make Malaya their permanent home and object of their loyalty or not - all are Indians" (Indian Daily Mail, 24 June 1949). The membership of the MNIC would be restricted to Indians who considered Malaya as their permanent home and gave undivided loyalty. The government of Malaya, it was hoped, would grant citizenship based on these criteria. Nonetheless, the Federation of Malaya Agreement that came into force in February 1948 did not only grant citizenship based on these criteria. Thus the changes to the MIC constitution were viewed as not being a positive move (Indian Daily Mail, 7 July 1949). The effort to distinguish between Malayan Indians and India Indians at that stage was seen to likely create more difficulties for the Indian community. Other criticisms included the effort to change the name of the party from MIC to MNIC, and this was seen as a sign of weak leadership. The newspaper viewed Budh Singh as one of the main causes of the weakness of the MIC because of his weak leadership, inactivity and his dictatorial style (Indian Daily Mail, 5 July 1949).

Apart from the internal conflict in the MIC related to the issue of citizen and non-citizens, one other issue which occupied the attention of the MIC was the participation of the Ceylonese and Pakistan communities in the party. This issue had already been raised at the inauguration of the MIC in 1946. The MIC leaders felt that Ceylonese who accepted the aims and objectives of the MIC should be able to become members of the party as representatives of the community (Tamil Nesan, 8 October 1946). Thivy explained that Indians and Ceylonese could be 
categorised in the same group based on factors of history, geography, culture and language (Jananayagam, 23 June 1947). Thus, he urged the Ceylonese community to join the MIC and as proof of his encouragement pointed out several examples of Ceylonese who were not only MIC members but also held high positions in the party. According to Thivy, unity between Indians and Ceylonese in Malaya was an important element because "the destinies of Ceylon and India are inextricably woven together" (Indian Daily Mail, 24 June 1947). He advised all MIC members to receive "every Ceylonese who, aware of his past ties and future destiny, identifies himself with the oneness of the Indian race, politically, socially, economically and culturally" (Indian Daily Mail, 24 June 1947). However, this idea of unity was not well received by both the communities. This was because Ceylonese who became members of the MIC had to sacrifice their identity as a Ceylonese. Further, Indians who wanted to become members of the MIC also had to accept the Ceylonese as Indians (Jananayagam, 4 August 1947).

This identity issue aside, there were other difficulties related to the objective of achieving unity between the Ceylonese and the Indians. Before the war, there was dissatisfaction among the Indians when Ceylonese were categorised as Indians in the population census. The Indians were also not happy with the nomination of a Ceylonese as a representative of the Indian community in the Federal Legislative Council (Malaya Tribune, 7 July 1947). Further, under the Indian Independence League (IIL) a separate section, known as the Ceylon section, was created. This section was created following opposition from Indians of the participation of Ceylonese in the IIL as Indians. The desire of the majority of the Ceylonese to retain their distinct identity also contributed to the setting up of a separate Ceylon section in the IIL (Tamil Nesan, 18 June 1946).

After the Second World War, the Ceylonese community formed the Ceylon Federation of Malaya on 30 December 1945. The membership of the organisation was open to all Ceylonese in Malaya and Singapore. The emergence of the Ceylon Federation indicated that the Ceylonese community was not willing to shed their distinct identity. The president of the Ceylon Federation, E. E. C. Thuraisingham, for example, told Thivy, "to leave us alone to enjoy the rights we have obtained through our own efforts and to look elsewhere for members" (Malaya Tribune, 25 June 1947). The Indians, too, on the other hand, were not willing to accept the Ceylonese as Indians. Thus the advice of Thivy urging both the communities to unite was not taken seriously by both communities. The Indian Daily Mail criticised the advice of Thivy as baseless as "it is difficult to visualise any common political body or platform for the two, except in the nature of independent political units under a federation formed to further their common interests" (Indian Daily Mail, 28 June 1947). 


\section{THE MIC, THE FEDERATION OF INDIAN ORGANISATIONS AND THE CONGRESS OF INDIAN ORGANISATIONS}

Several conflicts outside the MIC also challenged seriously the ability of the MIC to become the main representative of the Indian community in Malaya. One of these concerns was the formation of the Federation of Indian Organizations (FIO) in 1950 which challenged the position of the MIC among the community. There was also an effort by some Indian leaders to attempt to unite the MIA, FIO and the MIC into a national organisation to be called the "Congress of Indian Organizations." In 1950, S. Shanmugam a member of the Malacca Local Council took the initiative to form a new Indian organisation. Shanmugam intended to form an organisation to represent Indians who were born in Malaya. But this objective eventually changed with the formation of the FIO that was intended as a merger of Indian organisations that existed in Malaya at the time. According to Shanmugam, the other communities had their own organisations and there was a need for such an umbrella organisation to represent the voice of the Indians to the government of the federation: "While the Chinese and the Malays had their own organisations, namely the MCA and UMNO, to represent their views to the Government, the Indians born and domiciled in the Federation have no medium through which our rights as citizens under the existing Government or as future citizens of selfgoverning Malaya can be voiced" (Indian Daily Mail, 19 April 1950).

The above statement showed clearly that Shanmugam did not consider the MIC as the representative of the Indians in Malaya. He felt that the MIC did not have a sufficient membership, leaders of calibre and that its policies were unclear (Indian Daily Mail, 19 April 1950). Shanmugam stressed the importance of the formation of a new political organisation to represent Indians born in Malaya in the government and cabinet that would be formed in the future. To him it was clear that the other communities would be represented in the government whereas the MIC at the time was still continuing its boycott of the government and the 1948 federation constitution. It would thus be inevitable that any proposals in the Cabinet that would be formed would not include the voice of the Indian community. Shanmugam explained that the MIC could continue to hold on to its boycott position but "Malayan Indians who wished to be heard in a future independent Malaya should form an organization for themselves and participate actively in politics" (Indian Daily Mail, 19 April 1950). The failure to do so would result in the Indians not being accepted as a minority community by the government.

Shanmugam's idea to form a new political organisation to represent the Indians was criticised by the Indian Daily Mail. While accepting that the Indian community should not be allowed to be marginalised by the government, the newspaper did not agree with his plan to set up a new communal organisation (Indian Daily Mail, 19 April 1950). The newspaper felt that there was no reason to 
set up another communal organisation to represent those termed as Malayan Indians and argued that they could join the MIA if they wanted to be heard. Despite this criticism, Shanmugam's idea received much support from Indian representatives in the Federal Legislative Council and State legislatures. They nonetheless modified Shanmugam's idea of a new organisation to represent Indians born in Malaya, to that of an organisation that would "represent all shades of Indians" opinion in Malaya (Indian Daily Mail, 4 July 1950). The suggestion was for the formation of a new organisation that would bring together the 160 Indian organisations that existed in Malaya at the time (Indian Daily Mail, 4 July 1950). The proposed merger of these organisations, it was hoped, could focus on the economic, political and social developments of the Indian community in Malaya under a single organisation to be called the Federation of Indian Organizations (FIO) (see Federation of Indian Organisations File 1341/50). The membership of the FIO would be limited to organisations.

Apart from the Indian Daily Mail, the MIC and the MIA also opposed the effort to form the proposed FIO. The MIC argued that if the FIO was formed it would be an organisation that would be similar to the MIC (Letter from MIC general secretary S. Govindaraj dated 14 July 1950 to all branches). The formation of a new organisation with individual membership was viewed as a challenge to existing Indian organisations. R. Ramani, a prominent Tamil lawyer, explained that FIO membership would be limited to organisational membership to avoid this conflict of interest (Singapore Standard, 2 September 1951). The 13 Indian officials who initiated the move to set up the FIO explained that the proposed organisation would not be a substitute for the existing Indian organisations:

FIO would not be a primary or a parallel organization comparable to any existing organization and designed to be a substitute for it, but a federation deriving its strength solely from existing organizations and thereby indirectly strengthening such existing organization, leaving them unfettered in their particular tasks.

(Indian Daily Mail, 4 July 1950)

The MIC explained that existing Indian organisations had different aims and objectives and sometimes conflicted with one another. Thus, the MIC questioned the relevance of the merger of all the Indian organisations into the FIO, arguing that such an organisation would not be effective (Indian Daily Mail, 22 July 1950). The MIC contended that the formation of the FIO would not lead to greater cooperation between the Indian organisations, but rather would deepen the misunderstanding between these organisations that could then lead to the formation of more new organisations (Indian Daily Mail, 22 July 1950). 
The MIA contended that the FIO would be an organisation similar to the MIA. The FIO's objective to represent Malayan Indians was similar to the MIA's objectives. Thus the 13 Indian officials who had initiated the formation of the FIO were asked to reject the idea and instead join the MIA (MIA File No. 104/50, letter from the MIA secretary to the FIO organising chairperson). The MIA clarified that it would not agree to the idea of merging all Indian organisations that had political objectives. Nevertheless, the MIA said that if the merger was aimed at cultural, social and economic development of the Indians, the organisation would support it.

The Indian Daily Mail explained that most of the 13 Indian officials who initiated the FIO were members of the Federal Legislative Council and state and local councils (Indian Daily Mail, 5 July 1950). They opposed the MIC's policy to boycott the government and were willing to work with the government and accepted their appointments to the various councils. The MIC in its effort to continue the boycott policy had sacked the membership of several senior officials in the party. P. P. Narayanan and M. P. Rajagopal, who were members of the Federal Legislative Council, were among 12 officials who were sacked from the MIC in April 1948 (Indian Daily Mail, 12 April 1950). The move to form the FIO by the 13 officials was viewed by the MIC as an effort to obtain recognition from the government that the FIO was the representative of the Indian community in Malaya. It was contended that as soon as they obtained the recognition from the government, these officials would be considered for nomination to the Federal Legislative Council and town councils (Indian Daily Mail, 5 July 1950). The MIC at its fourth general assembly on 29 April 1950 decided to accept into the party officials who had been sacked for taking up nominations to the various councils. But those who had been sacked were not keen to return to the MIC because they felt that they would not be able to have much influence in the party or be accorded much importance in the party.

The FIO was officially formed on 22 July 1950 although it had received much criticism and opposition. Nevertheless, the FIO was not well received by the Indian community. From the 160 Indian organisations in Malaya only 56 replied to the letter proposing the formation of the FIO and out of these only 48 supported the proposal. At the formal inauguration of the FIO, only 21 organisations participated and 12 among these withdrew at the last minute as a protest against the formation of the FIO (Indian Daily Mail, 1 July 1950). Thus only nine Indian organisations remained with the FIO (Indian Daily Mail, 1 July 1950). As soon as the FIO was formed, the Indian Daily Mail and other Indian organisations that opposed the formation of the FIO attempted to expose the ineffectiveness of the FIO to represent the Indians in Malaya. A feature article in the Indian Daily Mail noted that the FIO Committee as a whole consisted of professionals and businessmen and could not be seen as representing the whole of the Indian community. The newspaper argued that $90 \%$ of the Indians in Malaya comprised ordinary workers while the 
remaining $10 \%$ comprised professionals and businessmen. Considering that the FIO Committee did not contain a representative of the Indian workers, such as P. P. Narayanan, who was the president of the All-Malayan Trade Union Council, and M. P. Rajagopal, who was the head of the Railway Workers Union, the FIO was accused of only representing the professional class and not the working class (Letter from MIC General Secretary, S. Govindaraj, 14 July 1950).

The MIC, MIA and nine other Indian organisations that were opposed to the formation of the FIO held a protest meeting on 25 July 1950 (Indian Daily Mail, 26 July 1950). These organisations expressed regret over the formation of the FIO and agreed at the meeting that the FIO would have a negative impact on the Indians in Malaya because it merely contributed to an increase in Indian organisations (Indian Daily Mail, 26 July 1950). They noted that only a very small portion of the 160 Indian organisations in Malaya had supported the formation of FIO. In this context, an effort was made in 1951 to unite the MIC, MIA and FIO into a single organisation to be called the "Congress of Indian Organizations." The idea to unite the three organisations came from Padi A. Krishnan on 19 April 1951 (see MIA File No. 104/50 and Malay Mail, 22 May 1951). Krishnan stressed the importance of the need to unite the three associations in order to cooperate with the $\mathrm{UMNO}$ and the MCA in the context of the developments taking place in Malayan politics (see MIA File No. 104/50). The MIC Working Committee discussed the proposal and supported the call to unite the three organisations (Minutes of the MIC Working Committee meeting, 29 April 1951). Five officials from each organisation met on 13 May 1951 and agreed in principle that the organisations merge into a single body called "Congress of Indian Organizations" (Indian Daily Mail, 14 May 1951). The membership of the new organisation would be individual and organisational membership. A small committee comprising Ramani, president of FIO, G. V. Thaver, MIA president, and K. L. Devaser, the MIC president, was formed to formulate the constitution and rules of the new organisation. It was agreed that after the draft constitution was formulated, the MIC, the MIA and the FIO would dissolve their respective organisations (see MIC Working Committee minutes, 2 June 1951; Straits Times, 14 May 1951).

Nevertheless, the idea of uniting these three Indian organisations faced considerable difficulties. The three organisations had conflicting ideas on the nature of the new organisation, including on important matters such as the objectives of the organisations, its structure and membership (Letter from S. Govindaraj to K. L. Devaser, 16 April 1951). This was because the FIO had an organisational membership while the MIC and the MIA had individual membership (Straits Times, 2 September 1951). This raised the question of the suitability of the FIO becoming a member of a main organisation. Thus the three organisations agreed that there would be a duality in membership in the new organisation - single membership and organisational membership. Another issue that had not been seriously considered 
in the process of uniting the three organisations, and which served as an obstacle, was related to representation in government bodies (Singapore Standard, 21 May 1951). The differences between the three organisations would inevitably lead to difficulties in choosing representatives in the government bodies. The FIO could not accept representation based on individual basis because it was an organisation based on organisational membership. If the representation was based on organisational membership the FIO would have some advantage. But this would be opposed by the MIC which had large individual membership. Despite these difficulties the idea of uniting the three organisations was well-received among the Indian community. The Tamil Nesan reported the first meeting of the three organisations on 13 May 1951 as pleasant news for the Indian community in Malaya (Tamil Nesan, 15 May 1951). Interestingly, the idea of a union of these three organisations was wellreceived by the All-India Radio (Malay Mail, 22 May 1951).

The debate over the membership of citizens and non-citizens in the formation of the Congress of Indian Organizations, which was debated in the Indian Daily Mail (Indian Daily Mail, 16 May 1951), became a major issue in these talks. The FIO was not too particular about the membership of the new organisation being limited to citizens only. The MIA, on the other hand, while also agreeing not to restrict membership to citizens, argued that if the organisation was to be a political organisation, then membership and the right to vote should be restricted to those who made Malaya their permanent home (Indian Daily Mail, 14 August 1951). If this was not the case, the MIA felt, membership should be open to all sectors of the Indian community and representation should be given to all Indian associations. MIC President Devaser, on the other hand, argued that the objective of the Congress of Indian Organizations that was proposed was to represent the whole of the Indian community in Malaya and not restricted to Indians who made Malaya their permanent home (Tamil Nesan, 21 May 1951).

The idea of uniting the three associations was however temporarily discontinued when the MIC had its annual general assembly in June 1951 (CO 537/4786, Federation of Malaya Political Report, July 1951). Following the annual session of the MIC, Devaser wrote to MIA and FIO in August 1951 stating that the MIC unanimously agreed at its session that "any political body that may be formed must have only primary membership" (Letter from K. L. Devaser to R. Ramani, 5 August 1951). This condition that was proposed by the MIC was not acceptable to the MIA and FIO which reminded the MIC that their meeting of 13 May 1951 had agreed to individual and organisational memberships. This new condition disrupted the talks as the MIC reiterated that the new organisation should be made up of individual membership only although it did not end entirely the efforts to unite the three organisations. Three months later, Devaser wrote to MIA and FIO seeking renewed talks between the three organisations following a discussion on the issue by the All-Malayan Indian Congress Committee (AMICC). The MIC 
sought feedback from its branches on AMICC decision on individual membership and there was mixed response. Some MIC branches agreed to this while others disagreed. Some branches were also opposed to any change of the MIC's name while others suggested an open conference on the issue. The MIC was not able to reach a consensus on the idea of uniting the three organisations and no progress was made and the idea of uniting the three organisations was not pursued further.

\section{CONCLUSION}

The discussion above shows that the MIC faced considerable challenges within the party and strong rivalry from other Indian organisations in Malaya in the early period of the party's formation on a range of issues and in its effort to become the leading voice of the Indian community. The issue of citizenship was a central issue in the early struggles of the MIC following the introduction of the Malayan Union citizenship in 1946. The MIC was more inclusive in the representation of the Indians, regardless of whether they had obtained citizenship or not, as long as they made Malaya their home and object of loyalty. Hence the MIC was able to obtain wider support from the Indian community compared to the MIA and the FIO which represented Malayan-born Indians. The MIC decided to boycott the 1948 Federation of Malaya Agreement and the government because the nonMalays were not consulted over the formulation of the agreement and the stricter citizenship requirements introduced. Within the party, there was some opposition to the MIC's boycott of the 1948 constitution and the government, and this weakened the party after several leaders were sacked by the party for defying the boycott order. There were also some difficulties with local trade unions over the party's plan to introduce a "labour department" within the party. The MIC later discontinued its boycott of the 1948 Federation constitution. On another level, the MIC faced considerable challenges from several other Indian-based organisations for leadership of the Indian community. The biggest challenge came from the MIA and the FIO which also sought to become the main representatives of the Indian community in this early period. Efforts to unite the three organisations the MIC, MIA and FIO - did not materialise because of conflicting views between these organisations. The MIC was resolute in leading the community, and with some adjustments to its policy positions, abandonment of its boycott of the 1948 constitution, and some shrewd political manoeuvres, was able to overcome the challenge from the other organisations to become the leading party of the Indian community by 1950 . 


\section{REFERENCES}

\section{Primary Sources}

\section{National Archives of Britain}

CO 537/2562 (37), Nationality of Indians in the colonies after separation of India.

CO 537/6019 (11), Pan-Malayan intelligence report, "Political developments - Indian and Pakistani affairs", June 1949.

CO 537/4786 (38), Indian Affairs - Malayan Indian Congress. Extract from the Federation of Malaya Political Report for July 1949.

\section{National Archives of Malaysia}

Federation of Indian Organisations File 1341/50.

MIA File No. 104/50, Letter from the MIA secretary to the organising chairperson of the formation of the FIO.

MIA File 104/50, Registrar of Societies, Kuala Lumpur. Report of the Supervisor from the Registrar of Societies.

MIC File, 114/58, Registrar of Societies.

Rules of the MIA in Malayan Indian Association, File 104/50, Registrar of Societies, Kuala Lumpur.

UMNO/SG, File No. 113/50, UMNO Circular dated 29 November 1950.

Jananayagam, 1946-1947.

Malay Mail, 22 May 1951.

Malaya Tribune, 1947-1949.

Tamil Nesan, 1946-1951.

\section{National Library of Singapore}

Indian Daily Mail, 1947-1951.

Singapore Standard, 1950-1951.

Straits Times, 1947-1951.

\section{Universiti Malaya Library}

Annual Report of the MIC General Assembly, 1947/1948.

John Thivy papers. Draft proposal of All-Malayan Indian Organization presented at the All-Malayan Indian Conference in Kuala Lumpur, 3-5 August 1946.

MIC Annual Report, 1946/1947. 


\section{Universiti Sains Malaysia Library}

A. Balakrishnan's private papers. MIC President Budh Singh's speech at the Third Annual General Assembly of the MIC, 1949.

Letter from MIC general secretary, S. Govindaraj to all MIC branches, 14 July 1950.

Letter from S. Govindaraj to K.L. Devaser, 16 April 1951.

Letter from K. L. Devaser to R. Ramani, 5 August 1951.

New draft MIC Constitution, 1949.

MIC Working Committee minutes, 2 June 1951.

Minutes of the MIC Working Committee meeting on 29 April 1951.

Report of Malayan Union Advisory Council Proceedings, 1947-1948.

\section{Secondary Sources}

Ampalavanar, R. 1981. The Indian minority and political change in Malaya, 1945-1957. Kuala Lumpur: Oxford University Press.

Anbalakan, K. 2015. Political expediencies and the process of identity construction: The quest for Indian identity in Malaysia. Kajian Malaysia 33(1): 1-18. . 2008. Identiti India di Malaysia. Pulau Pinang: Penerbit Universiti Sains Malaysia.

Arasaratnam, S. 1970. Indians in Malaysia and Singapore. Kuala Lumpur: Oxford University Press.

del Tufo, M. V. 1949. Malaya: A report on the 1947 census of population. London: Crown Agents.

Lebra, J. C. 1971. The Indian national army and Japan. Singapore: Institute of Southeast Asian Studies.

Mahajani, U. 1960. The role of Indian minorities in Burma and Malaya. Bombay: Vora and Company Ltd.

Ratnam, K. J. 1965. Communalism and the political process. Kuala Lumpur: Oxford University Press.

Sandhu, K. S. 1969. Indians in Malaya: Some aspects of their immigration and settlement, 1786-1957. Cambridge: Cambridge University Press.

Stenson, M. R. 1980. Class, race and colonialism in West Malaysia: The Indian case. Queensland: The University of Queensland Press.

Stockwell, A. J. 1979. British policy and Malay politics during the Malayan Union experiment, 1946-1948. Kuala Lumpur: Malaysian Branch of the Royal Asiatic Society. 